\title{
Asymptomatic meningococcal urethritis Possible protective value against gonococcal infection by bacteriocin production
}

\author{
JAMES VOLK* AND STEPHEN J. KRAUS \\ Venereal Disease Research Unit, Laboratory Division, Center for Disease Control, Health Services and Mental \\ Health Administration, Public Health Services, U.S. Department of Health, Education, and Welfare, Atlanta, \\ Georgia 30333
}

\begin{abstract}
Neisseria species other than $N$. gonorrhoeae have been reported to cause symptomatic urethritis in the male. Carpenter and Charles (1942) described seven such cases due to the meningococcus in which there were no signs or symptoms of meningococcaemia. Although several authors have described asymptomatic urethral carriers of $N$. gonorrhoeae (Bittiner and Horne, 1955; Landman and Gelmi, 1959; Pariser, Farmer, and Marino, 1964), there have been no reports of asymptomatic urethral infections by other Neisseria.

We believe this to be the first report of asymptomatic meningococcal urethritis. The strain isolated from this patient is the first meningococcus reported to produce a bacteriocin with antigonococcal activity. Evidence is presented for the possible role of this bacteriocin in providing protection against gonococcal urethritis in vivo.
\end{abstract}

\section{Case reports}

Case 1, a 20-year-old white man, who had had sexual intercourse once 3 weeks previously, was diagnosed as having acute gonorrhoea on April 19, 1972. His only sexual contact was Case 2.

Case 2, a 20-year-old white female, was examined 7 days later, along with her regular consort (Case 3). Cervical cultures yielded oxidase-positive Gram-negative diplococci. These organisms were identified as gonococci by their utilization of glucose, but not maltose, sucrose, or lactose.

Case 3, a 20-year-old white male, was asymptomatic and showed no evidence of urethral exudate, but a culture from the urethral meatus grew oxidase-positive, Gram-negative diplococci which utilized both glucose and maltose. Bacterial agglutination performed by our

Received for publication February 2, 1973.

^Present address: Dr. J. Volk, M.D., Department of Pediatrics,

Northwestern University School of Medicine, Chicago, Illinois, U.S.A.
Special Bacteriology Laboratory identified these as sero-Group B meningococci. This patient was recalled to the clinic 5 days after the initial examination, and although he continued to deny any symptoms, a slight urethral exudate was expressed by vigorously stripping the penis. Microscopic examination of this exudate showed a few polymorphonuclear leucocytes and several Gram-negative diplococci which were primarily associated with epithelial cells. Cultures obtained at this time again showed oxidase-positive, Gram-negative diplococci which had the typical oxidative pattern of meningococci.

Cultures frozen for subsequent investigations were successfully subcultured 6 weeks later. When standard techniques for the demonstration of bacteriocin production were used (Fredericq, 1957), the $N$. meningitidis strain from Case 3 showed marked growth inhibition of the $N$. gonorrhoeae strain from Case 2.

\section{Discussion}

The origin of the meningococcal infection in Case 3 is uncertain. Harkness (1950) believed that most cases of urethritis caused by non-gonococcal Neisseria were transmitted from the nasopharynx of the female to the male genital tract by oro-genital contact. It is significant that the patients in the present study admitted frequent use of this sexual practice.

Although oral contact with male genitalia is a common sexual practice (Kinsey, 1953), Neisseria other than the gonococcus have rarely been isolated from the urethra. The case described above is only the eighth instance of meningococcal urethritis reported and this is the first report of the condition being asymptomatic.

Bacteriocins are antibacterial substances of a protein nature that are produced by a wide variety of bacteria and act on bacteria of the same or related species (Fredericq, 1957). Kingsbury (1966) has shown that some $N$. meningitidis strains produce 
bacteriocins which have an effect in vitro on other Neisseria species-N. perflava, N. subflava, and $N$. flavescens. The meningococcal strain recovered from the patient presented here (Case 3 ) is the first to be reported which produces a bacteriocin with activity against $N$. gonorrhoeae.

Epidemiological evidence has shown that a single exposure to an infected female does not invariably lead to gonorrhoea in the male (Holmes, Johnson, and Trostle, 1970). However, it is unusual for regular consorts to be spared if either partner contracts the disease. Cases 2 and 3 admitted having intercourse five to six times per week during a 4-week period in which Case 2 was known to be infectious. Because a condom or other protective device was not used, we postulate that the urethral meningococci and resultant antigonococcal bacteriocin of Case 3 may have offered protection against gonococcal infection from Case 2 .

\section{Summary}

Inhibition of $N$. gonorrhoeae in vitro by a meningococcal bacteriocin is described. The meningococcus was isolated from the urethra of an asymptomatic male who, despite frequent coitus with a woman who had cervical gonorrhoea, did not develop gonococcal urethritis. The hypothesis is presented that the meningococcus may have prevented gonococcal infection by production of the antigonococcal bacteriocin in vivo.

\section{References}

BitTiner, J. B. and HoRne, G. O. (1955) Brit. F. vener. Dis., 31, 155

Carpenter, C. M., and Charles, R. (1942) Amer. $\mathcal{F}$. publ. Hlth, 32, 640

FredericQ, P. (1957) Annual Rev. Microbiol., 11, 7

HARKNESS, A. H. (1950) 'Non-gonococcal Urethritis', p. 35. Livingstone, Edinburgh

Holmes, K. K., Johnson, D. W., and Trostle, H. J. (1970) Amer. F. Epidemiol., 91, 170

KINGSBURY, D. T. (1966) F. Bact., 91, 1696

KINSEY, A. C. (1953) 'Sexual Behaviour in the Human Female', p. 257. Saunders, Philadelphia

Landman, G. S., and Gelmi, O. (1959) Sth. med. F. (Bgham, Ala.), 52, 750

Pariser, H., Farmer, A. D., and Marino, A. F. (1964) Ibid., 57, 688

Urétrite méningococcique asymptomatique. Valeur protectrice possible de la production de bactériocine contre l'infection gonococcique

SOMMAIRE

On décrit l'inhibition in vitro de $N$. gonorrhoeae par une $ᄋ$ bactériocine méningococcique. Le méningocoque avaito été isolé de l'urètre asymptomatique d'un homme qui, malgré de fréquents coïts avec une femme atteinte decos gonococcie cervicale, n'avait pas présenté d'urétrite gonococcique. On évoque l'hypothèse que le méningocoque puisse avoir empêché l'infection gonococcique grâce à la production in vivo de bactériocine anti-gonococcique. 